\title{
As percepções da paisagem e as diferentes dinâmicas das bordas do Maracanã
} The landscape's perceptions of the different dynamics of Maracanã's borders

\section{Percepciones del paisaje y las diferentes dinámicas de la frontera del Maracanã}

CHAVES, Adriane Pacheco ${ }^{1}$ REGO, Andrea Queiroz ${ }^{2}$

ROLA, Sylvia Meimaridou ${ }^{3}$

Universidade Federal do Rio de Janeiro, Faculdade de Arquitetura e Urbanismo, Programa de Pós-Graduação em Arquitetura. Rio de Janeiro, RJ, Brasil.

1 arq.adrianepacheco@gmail.com ORCID: 0000-0002-9630-8303

2 andrea.queiroz@fau.ufrj.br ORCID: 0000-0002-3801-8017

3 sylvia.rola@fau.ufrj.br ORCID: 0000-0001-6321-8857 


\title{
Resumo
}

Para atender as recomendações da Fédération Internationale de Football Association - FIFA -, para a Copa do Mundo de 2014, foram executadas construções/transformações arquitetônicas e urbanísticas em 14 estádios no Brasil visando convertê-los em "arenas". Na cidade do Rio de Janeiro, no Estádio do Maracanã as obras ocorreram no edifício e no espaço livre do entorno imediato. Essas obras modificaram as paisagens e, consequentemente, padrões de uso, apropriações e representações da área. Novas identidades foram percebidas $e$ as antigas reinterpretadas por novas dinâmicas relacionadas com as dimensões físicas, urbanas e de inclusão social. $\mathrm{O}$ objetivo deste trabalho foi estudar as diferentes bordas que margeiam o Estádio do Maracanã observadas nos momentos de eventos e no cotidiano, definidas por seus atributos biofísicos, urbanísticos e socioculturais, além de buscar compreender o quanto a urbanização da borda "padrão FIFA" descaracterizou o espaço, priorizando os sistemas de evacuação em prol da humanização e ambiência. Através de estudos cartográficos e iconográficos, levantamentos de fluxos e percursos comentados procurou-se analisar e compreender a maneira como o usuário vivencia as bordas em dias de eventos, particularmente nos jogos de futebol do Clube de Regatas Flamengo onde toda disputa é considerada um megaevento, e de que maneira o acontecimento impacta seu entorno.

Palavras-Chave: Impactos; Espaço livre; Percurso Comentado

\begin{abstract}
To meet FIFA's recommendations for the 2014 World Cup, it was executed several architectural and urban constructions/transformations in 14 stadiums in Brazil to convert them into "arenas." In the city of Rio de Janeiro, at the Maracanã Stadium to be more specific had its works taking place not only in the building but also in the free space and immediate surroundings. These works brought changes in the landscapes resulting in the new modes of used patterns, appropriations, and representations of the area. New identities were perceived while old ones were reinterpreted by new dynamics related to the physical, urban, and social inclusion dimensions. The goal of this work is to study each three different borders that surround the Maracanã Stadium detected during each event, defined by their biophysical, urban, and socio-cultural attributes. According to cartographic and iconographic studies, flow surveys, and commented routes, we are looking to comprehend how the people experiences the edges in days that have events, especially the Flamengo soccer games, where each game is a megaevent and how it impacts its surroundings.
\end{abstract}

Key-Words: Impacts; Open Space; Commented route

\section{Resumen}

Para cumplir con las recomendaciones de la Fédération Internationale de Football Association - FIFA para la Copa del Mundo de 2014, evento llevaron a cabo diversas construcciones/transformaciones arquitectónicas y urbanas en 14 estadios en Brasil para convertirlos en "arenas." En la ciudad de Río de Janeiro más específicamente en el Estadio Maracanã, las obras se llevaron a cabo no solo en el edificio, pero también en el espacio libre y entorno inmediato. Estas obras trajeron cambios en los paisajes y en consecuencia, en los nuevos modos de patrones de uso, apropiaciones y representaciones del área. Se perciben nuevas identidades y sé reinterpretadas por nuevas dinámicas relacionadas con las dimensiones de inclusión física, urbana y social. El objectivo de este trabajo es estudiar las tres fronteras distintas que rodean el Estadio Maracaná detectadas en los momentos de los hechos, definidas por sus atributos biofísicos, urbanos y socioculturales. Y entender la urbanización del borde "estándar FIFA", caracterizando mal el espacio, priorizando los sistemas de evacuación a favor de la humanización y la ambientación. A través de estudios cartográficos e iconograficos, levantamientos de flujos y recorrido comentado buscamos entender como el usuario vivas las aristas en días de eventos, en particular los juegos de futbol del Flamengo en los que todo el juego es un mega evento, y como impacta su entorno.

Palabras clave: Impactos; Espacio libre; Ruta comentada 


\section{Introdução}

O calçadão do Maracanã sempre se apresentou como borda, área de fronteira, desde os tempos da coroa, quando, inicialmente sua área estava anexada ao Palácio da Quinta da Boa Vista. Mais tarde, o espaço foi se modificando em função da expansão da cidade.

A Copa do Mundo de 2014 e os Jogos Olímpicos de 2016 que aconteceram no Brasil acarretaram impactos arquitetônicos, urbanísticos e nos espaços livres. Os megaeventos realizaram uma das intervenções mais polêmicas na Cidade do Rio de Janeiro que foi a reconfiguração do Estádio Jornalista Mario Filho, o Maracanã, um dos estádios mais famosos do mundo, palco da final da Copa do Mundo de futebol de 1950. Desde então, o edifício vinha servindo como um espaço público multiuso, recebendo milhares de pessoas de todo o mundo. A partir de 2005, no entanto, o Maracanã sofreu intervenções radicais e hoje em dia só mantém a arquitetura externa da sua estrutura original, uma vez que foi descaracterizado por dentro e por fora. Seu calçadão foi alvo de transformações desde a sua construção, mas foi principalmente após a reforma de 2014 que tais mudanças acarretaram conflitos culturais e funcionais, tanto na borda quanto no entorno urbano imediato. $O$ espaço livre público, que ora se apresenta como local de interação e sociabilização, é importante para a combinação de usos no tecido urbano. Porém, os novos padrões de construção e reconstrução afetaram seu uso e identidade originais e acabaram interferindo em um dos verdadeiros "templo do esporte", exemplo de lugar com uma identidade que perpassa gerações e detém uma memória social constituída pelas inúmeras representações, desde a sua concepção até os nossos dias.

Neste estudo pretendeu-se mostrar como as três diferentes bordas ${ }^{1}$ que rodeiam o Estádio, impactam o ambiente, além de tentar compreender o quanto a urbanização de suas bordas, segundo o "padrão FIFA", descaracterizou e influenciou negativamente o espaço, priorizando os sistemas de evacuação, ainda que os cadernos de encargos determinassem características de humanização e ambiência. Para tanto, foi utilizada metodologia de "percurso comentado" ${ }^{2}$ desses espaços nos momentos de eventos, particularmente durante jogos de futebol do Clube de Regatas Flamengo, e no dia a dia.

O instrumento utilizado para a representação "cartografia de percurso" fundamentada no método "percurso comentado" mostra como as maneiras de caminhar mobilizam e configuram um campo de variáveis heterogêneas, e propiciam, a cada vez, uma versão possível do contexto no qual se inserem (THIBAUD, 2008).

\section{Desenvolvimento}

As bordas do Estádio do Maracanã estão incluídas no sistema de espaços livres, e esses espaços são fruto do processo de urbanização e formação (MACEDO, 2012). O parcelamento do solo, as construções e o arruamento deram origem a inúmeras tipologias de espaços e diversas formas de apropriação dos mesmos. Tendo ou não sido criados para uso específico, permitem apropriações diversificadas - o espaço livre, torna-se palco para diversas formas de expressão da sociedade. São espaços de encontro, lazer, práticas esportivas e manifestações.

As bordas se apresentam como espaços públicos, de uso comum, de propriedade pública, abertos e

1 Após a finalização do estudo foram detectadas três bordas: Borda permanente (1) que corresponde ao calçadão que margeia o estádio do Maracanã, e duas Bordas denominadas Variáveis (2) que geograficamente abrange as ruas locais do entorno imediatos e as coletoras av. Maracanã e av. São Francisco Xavier e (3) a última Borda de ocupação abrange as duas bordas anteriores se expandindo até o Shopping Tijuca.

2 Segundo Thibaud (2008) o Percurso Comentado é feito quando o pesquisador sombra caminha junto ao torcedor e analisa a sua percepção. É registrado por vídeos e fotografias e representado cartograficamente, indicando as manchas de dispersão dos torcedores e os locais de concentração (THIBAUD, 2008). 
de livre acesso no dia a dia, havendo, no entanto, restrição ao público quando acontecem eventos. Em alguns momentos os espaços livres são considerados inseguros e seu desenho pode não ser adequado às atividades públicas, ao estar, ao lazer e à comunicação. As bordas do estádio, quando incorporadas ao sistema de espaços livres urbanos, deveriam apresentar relações de conectividade e complementaridade. Porém, o que acontece é a desertificação cotidiana confrontante com o "mar de gente" que se apropria do entorno em dia de evento, mesmo que não tenha sido projetada para tal (MACEDO, 2008).

Morfologicamente, a área margeada pelo rio Maracanã apresenta-se como um território dotado de suas próprias marcas e signos de delimitação, demarcando áreas diferentes, gerando separações e suturas (Figura 1). A borda põe em dúvida o sentido do espaço público que se pressupõe fisicamente contínuo e social e culturalmente universal; atualiza, expressa e significa diferentes espacialidades e temporalidades da cidade (ARROYO, 2007). Contudo, os elementos presentes nesse espaço se organizam e se orientam através da multidão, sequenciando imagens que surgem passo a passo ao percorrer da cidade.

Figura1: Aerofotogramétrico do Estádio do Maracanã e sua hidrologia.

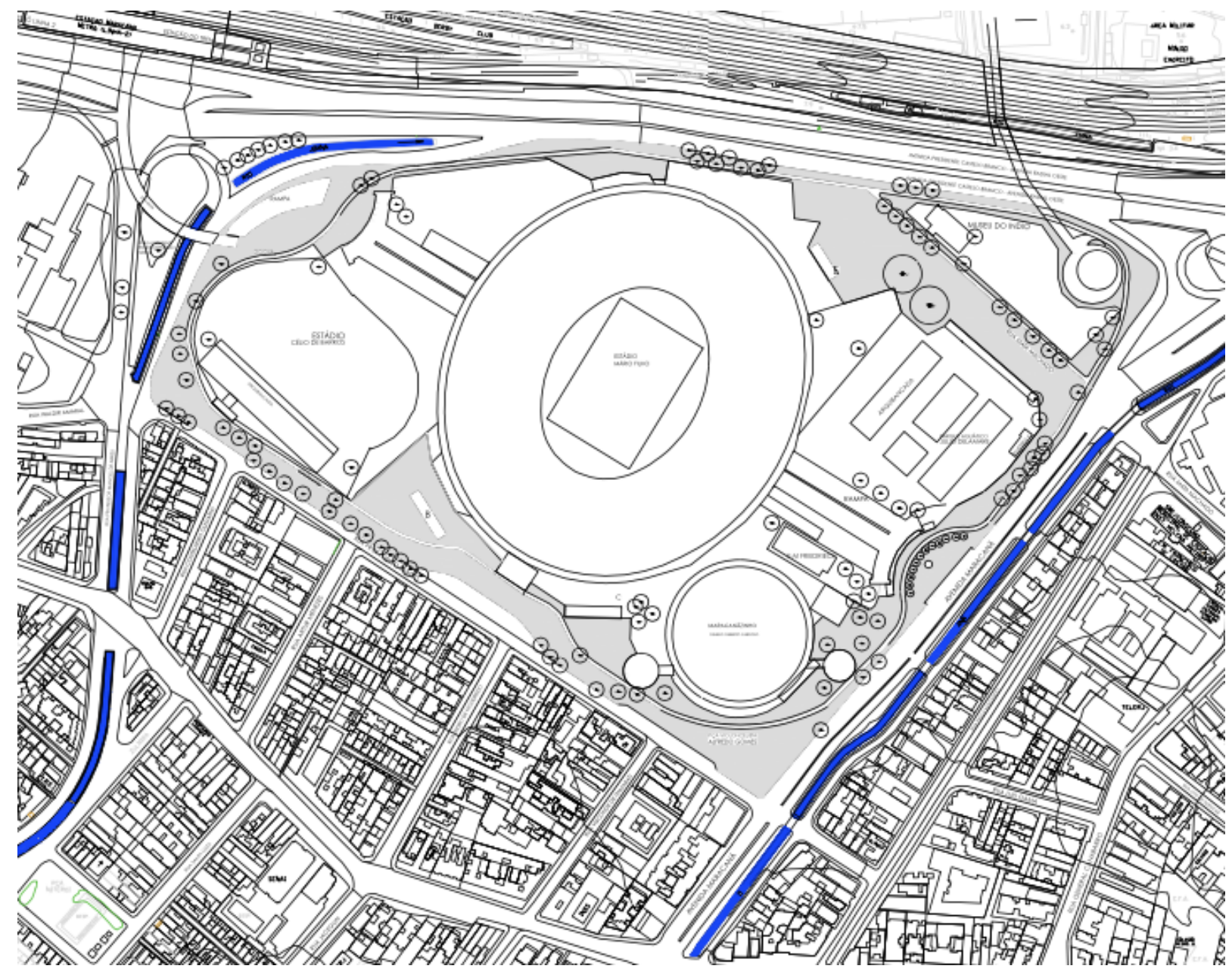

Fonte: Rio Dados, 2018.

A relação entre o indivíduo e a cidade é sempre uma experiência única e pessoal. Entretanto, os lugares possuem capacidade de transmitir mensagens que são interpretadas como revelação de certos sinais codificados (KOHLSDORF, 1996), tendendo a ter significações semelhantes para os membros de um mesmo grupo cultural. Assim, é possível compreender que os torcedores entendem o espaço 
urbano e arquitetônico por meio da experiência visual, criando uma base de vivências compartilhadas. Dessa forma, a existência de bordas, fronteiras ou limites são, por vezes, a essência das identidades urbanas (CULLEN, 2006). São espaços fenomenológicos, de problematização socioambiental e funcional, muitas vezes de ruptura social por proscrição, negação, segregação ou guetificação de grupos ou segmentos, de degradação ambiental, de desvalorização da paisagem e de desfuncionalidade por incompatibilidade de usos, déficit de serviços e obsolescência de infraestruturas.

Foi a partir dos anos 2000 que as obras reduziram drasticamente a capacidade do estádio (Tabela 1) nesse sentido. As tentativas de acabar com os equipamentos que fazem parte do complexo do Maracanã, como o Parque Aquático Julio Delamare (1), o estádio de atletismo Célio de Barros (2), Museu do Índio (3) e Escola Municipal Friedenreich_(4) não foram adiante. Havia uma poligonal de tombamento determinada pelo Instituto do Patrimônio Histórico e Artístico Nacional - IPHAN - que impedia as demolições e os movimentos populares reforçaram para que estas não acontecessem. Já o Maracanãzinho (5), que apresenta similaridades com o estádio de futebol, foi submetido a reformas e descaracterização (Figuras 2 e 3).

Figura 2: Localização dos equipamentos localizados no calçadão do Estádio do Maracanã

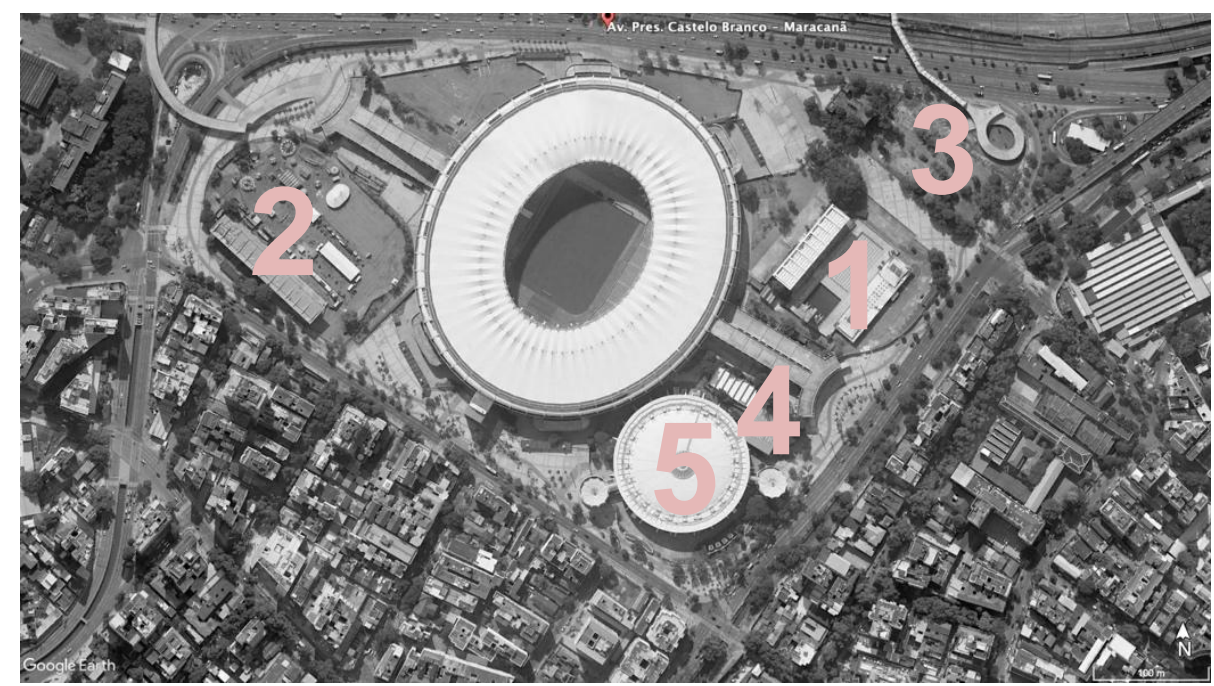

Fonte: Google Earth, 2018, trabalhado pelos autores. 
Figura 3: Equipamentos do complexo do Maracanã que correram risco de demolição

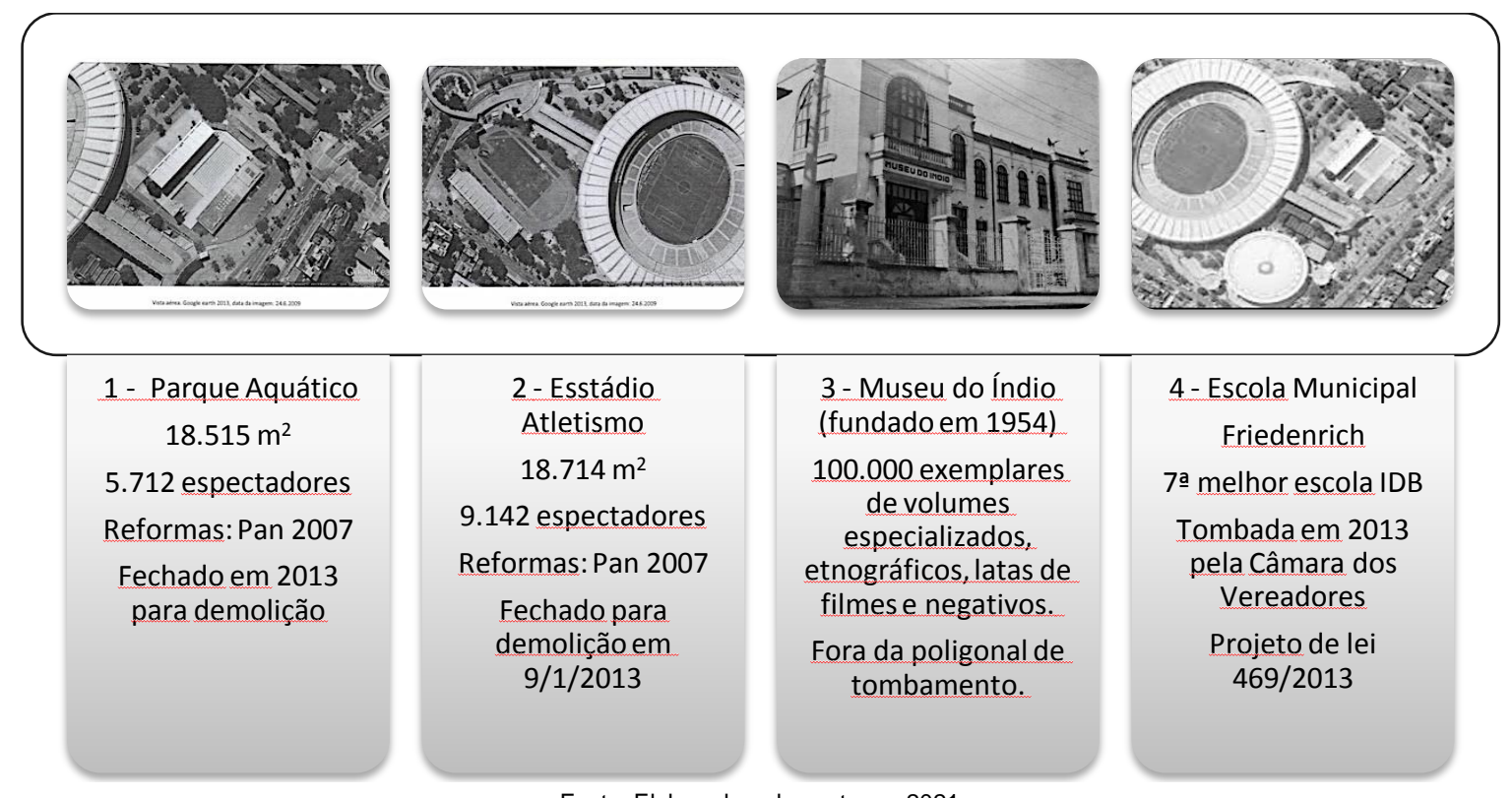

Fonte: Elaborado pelos autores, 2021

Tabela 1: Grandes Reformas do Maracanã.

\begin{tabular}{|c|c|c|c|}
\hline Data & Reforma & Finalidade & Capacidade \\
\hline 1948 & Construção & Copa do Mundo FIFA 1950 & 199.854 \\
\hline 1999 & Ampla reforma reduziu capacidade. & Mundial de Clubes FIFA 2000 & 103.022 \\
\hline 2005 & $\begin{array}{l}\text { Rebaixamento do campo; extinção } \\
\text { da "geral"; construção de mais duas } \\
\text { rampas de acesso; recuperação } \\
\text { estrutural das instalações e } \\
\text { tratamento e impermeabilização das } \\
\text { lajes da cobertura. }\end{array}$ & Jogos Pan Americanos 2007 & 87.795 \\
\hline 2010 & $\begin{array}{l}\text { Demolição da Cobertura e } \\
\text { remodelação geral "padrão FIFA". }\end{array}$ & $\begin{array}{l}\text { Copa das Confederações } \\
2013\end{array}$ & 73.531 \\
\hline 2014 & & Copa do Mundo FIFA 2014 & 74.738 \\
\hline
\end{tabular}

Fonte: site http://www.netvasco.com.br/mauroprais/futrio/6aracanã.html (2018)

Ainda assim, o ambiente que envolve o estádio do Maracanã teve vários usos e modificações. Cronologicamente, é possível evidenciar esses usos e aspectos da área ao redor do Maracanã, descritos a seguir. Em 1950, apenas os acessos ao estádio eram pavimentados; na década de 1970, havia estacionamentos margeando o estádio; na década de 1990, o calçadão era arborizado e inseguro com iluminação precária. A partir de 2014 a ampliação do passeio foi feita para atender aos parâmetros da FIFA e subtraiu quase toda a arborização existente (Figura 4). 
Figura 4: Aero fotos do Estádio do Maracanã em 11/06/2003 e 24/01/2014.
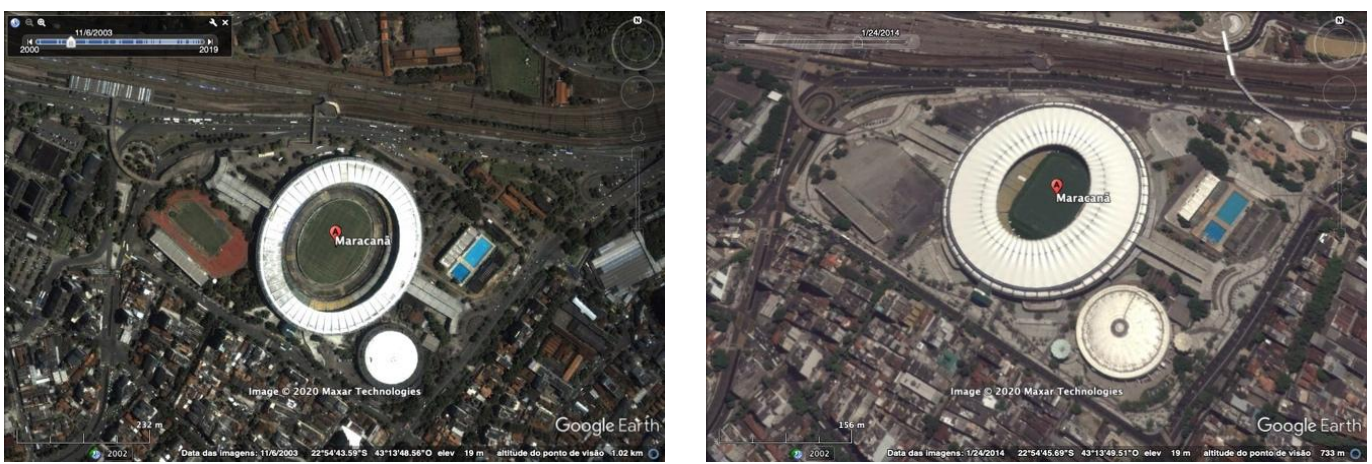

Fonte: Google Earth, 2018

A retirada da arborização e de mobiliários urbanos trouxeram impactos no calçadão e em seu entorno, ocasionando conflitos de subutilização da borda do Maracanã no cotidiano. As bordas põem em dúvida o sentido do espaço público que se pressupõe fisicamente contínuo e social, culturalmente universal e se atualizam, expressam e significam diferentes espacialidades e temporalidades da cidade. A problemática apresentada subsidia o objetivo deste estudo em entender as formas de apropriação do espaço público no entorno do estádio em momentos diversos, prioritariamente frente aos acessos e dispersões dos torcedores nos jogos do Flamengo possibilitando captar as três bordas de diferentes dinâmicas de ocupação.

\title{
2. Borda "PADRÃO FIFA"
}

Para as reformas do calçadão do estádio o governo viu-se "obrigado" a utilizar os parâmetros normativos que a FIFA impôs sem considerar as características socioambientais e culturais locacionais. O espaço foi dividido em Zonas, cuja correspondência geográfica seria: Zona 1, o espaço referente ao espaço público da cidade; Zona 2, indica que o espaço público se torna zona exclusiva ao evento FIFA; Zona 3, se refere ao cinturão de segurança pública em que só usa esse espaço quem porta ingresso do evento; Zona 4, corresponde à área imediatamente interna ao perímetro de segurança; Zona 5, representa o interior do estádio (Figura 5).

Figura 5: Especificação dos cinco perímetros de estádio em eventos FIFA.

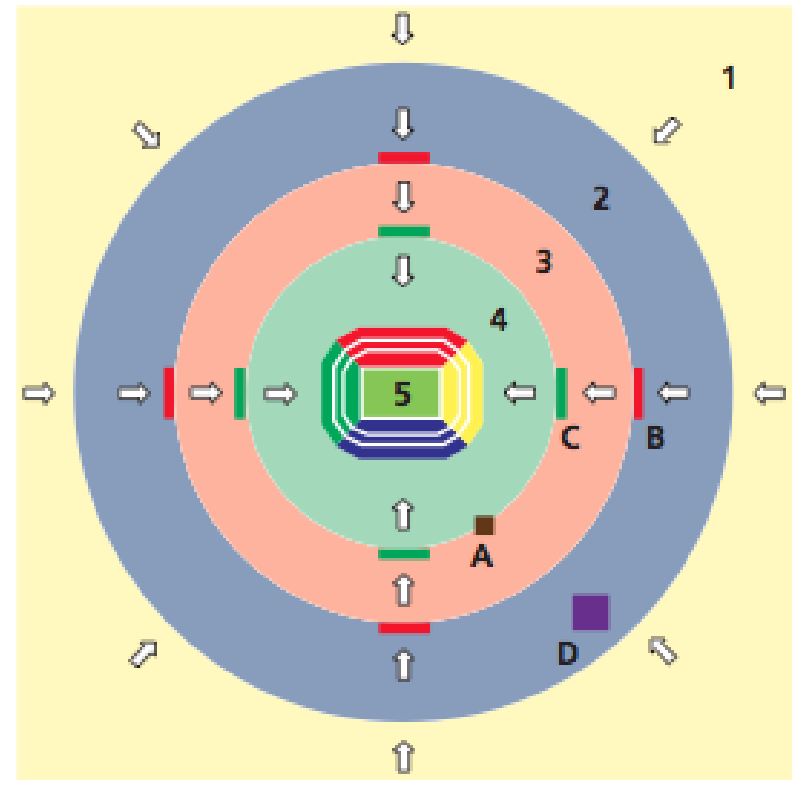

\author{
1. The public zone \\ 2. The exclusive zone \\ 3. Outer perimeter \\ (visual ticket check) \\ 4. Inner perimeter \\ (electronic access control) \\ 5. The stands \\ A. TCP \\ B. Mags \& bags \\ C. Turnstiles \\ D. STC
}

Notes:

TCP: Ticketing dearing point STC: Stadium ticketing centre

Fonte: Guia de Recomendações FIFA, 2007. 
O entorno dos estádios para eventos da FIFA se refere à de Zona 4, área em que na sua execução levou à desumanização da borda. Segundo o Guia de Recomendações da FIFA (2007) a Zona 4 (área de segurança final) é o local aberto, fora dos limites do fechamento do perímetro do estádio. Já para o Guia da Fundação Getúlio Vargas, em uma situação de emergência, esta Zona é a área permanente de segurança, aquela para a qual os espectadores podem escapar das arquibancadas passando pela Zona 3. Para isso, o local deve possuir uma superfície disponível capaz de receber a totalidade do público presente, considerando uma densidade de quatro a seis pessoas por metro quadrado. Em situação de uso normal, a Zona 4 oferece aos espectadores um cinturão de circulação livre, onde podem procurar um determinado portão de acesso (GUIA de Recomendações FIFA, 2011).

No caso do Maracanã as cinco zonas se distinguem em perímetro interno definido como o espaço que imediatamente envolve o edifício do estádio; esta zona é determinada pelas paredes do estádio. $\mathrm{O}$ perímetro externo é o local onde o pessoal oficialmente credenciado e portadores dos bilhetes têm o direito de transitar nos dias de jogo. Em resumo, a Zona 4 pode tanto servir como zona de segurança definitiva como atender à necessidade de uma zona de separação paisagística entre o estádio e seu exterior. O tempo máximo de evacuação do assento do espectador até a zona 4 de segurança deve ser de oito minutos. E a máxima distância permitida é de 30 ou 40 metros do assento do espectador para um lugar intermediário de segurança e para as saídas denominadas vomitórios.

O Guia FIFA especifica ainda sobre a Zona de Amortecimento, onde descreve que esta corresponde à transição entre o edifício do estádio e a área de estacionamento, a Zona 4, como foi descrita anteriormente. Um trecho dela deve ser pavimentado ou gramado para servir como área de reunião. Porém, sua parte remanescente pode ter árvores, arbustos ou mesmo floração, estas últimas preferencialmente junto aos portões de entrada. Assim, quanto à questão da vegetação presente e próxima aos estádios, o Guia da FIFA (2007) no item denominado "Uso do Plantio" mostra que a utilização de plantio denso de proteção em seu entorno pode aliviar o impacto visual causado pela sua volumetria, inserindo-a em seu contexto urbano. Embora com custo inicial e de manutenção alto, particularmente junto a estádios onde o comportamento descuidado do público pode ocorrer, essa solução deve ser tratada em paralelo com as obras e não deixadas para depois (FIFA, 2007). É permitido o plantio nas áreas de circulação dentro do perímetro do estádio para ajudar a definir os padrões de circulação e para auxiliar a separação do volume do edifício. Em razão dessas áreas serem ocupadas por multidões é recomendado que sejam plantadas espécies cujas folhagens não ultrapassem dois metros de altura, a fim de não atrapalhar a visão dos espectadores.

Todas as reformas executadas no edifício do estádio objetivaram diminuir a capacidade de público, visando a segurança dos usuários. Desde os incidentes que acarretaram grande violência da torcida em 1989 na Copa da Inglaterra, em Londres, no jogo Nothingham Forest contra o Liverpool, onde 96 torcedores foram a óbito e 200 ficaram feridos, essas medidas foram implantadas. E, no Brasil, no Maracanã, na final do campeonato brasileiro de 1992, onde jogaram Flamengo contra Botafogo, aconteceu a maior tragédia no Estádio. A superlotação com mais de 150.000 torcedores causou o rompimento de 13 metros de guarda corpo da arquibancada onde torcedores do Flamengo caíram sobre as cadeiras, também lotadas, resultando em 3 mortos e 82 feridos (Jornal O Globo,1992). O Maracanã foi interditado e após este incidente, ocorreu uma série de reformas para aumentar a segurança e atender às exigências da FIFA e do Comitê Olímpico Internacional para sediar os eventos como Copa e Olímpiada. Ademais, em 2010 foi sancionada a lei 12.299/10 denominada de Estatuto do Torcedor que prevê a proteção e segurança diante de certos parâmetros, como conforto e acessibilidade nos estádios de todo o território nacional.

Considera-se, aqui, as reformas que reduziram a capacidade do Estádio e não atenderam às regras do tombamento e as razões pelas quais a atual borda do Maracanã não foi construída reconhecendo a escala humana, criando uma transição entre a paisagem local do entorno e a monumentalidade do 
Estádio, uma vez que há indicativos paisagísticos definidos pela FIFA para tal.

\section{Estudo de caso: a borda do Maracanã}

A borda do Maracanã detém, atualmente, uma área de espaço livre de $12.000 \mathrm{~m} 2$. Porém, sua subutilização foi evidenciada em estudo de campo em dia de cotidiano para lazer ativo. Já a área de evacuação para eventos abriga um público médio de 50.000 pessoas.

Um dos pontos positivos da área é a mobilidade (Figura 6), visto que se trata de um dos poucos bairros do município em que mais de um modo de transporte público de massa abastece a região, como o metrô e trem, além de ônibus para todas as zonas da cidade, taxis e transportes por aplicativos. Porém, a região oferece poucas vagas de estacionamento para carros, ao lado da estação de metrô de São Cristóvão e no Shopping Tijuca.

Figura 6: Mapa de mobilidade da área de estudo

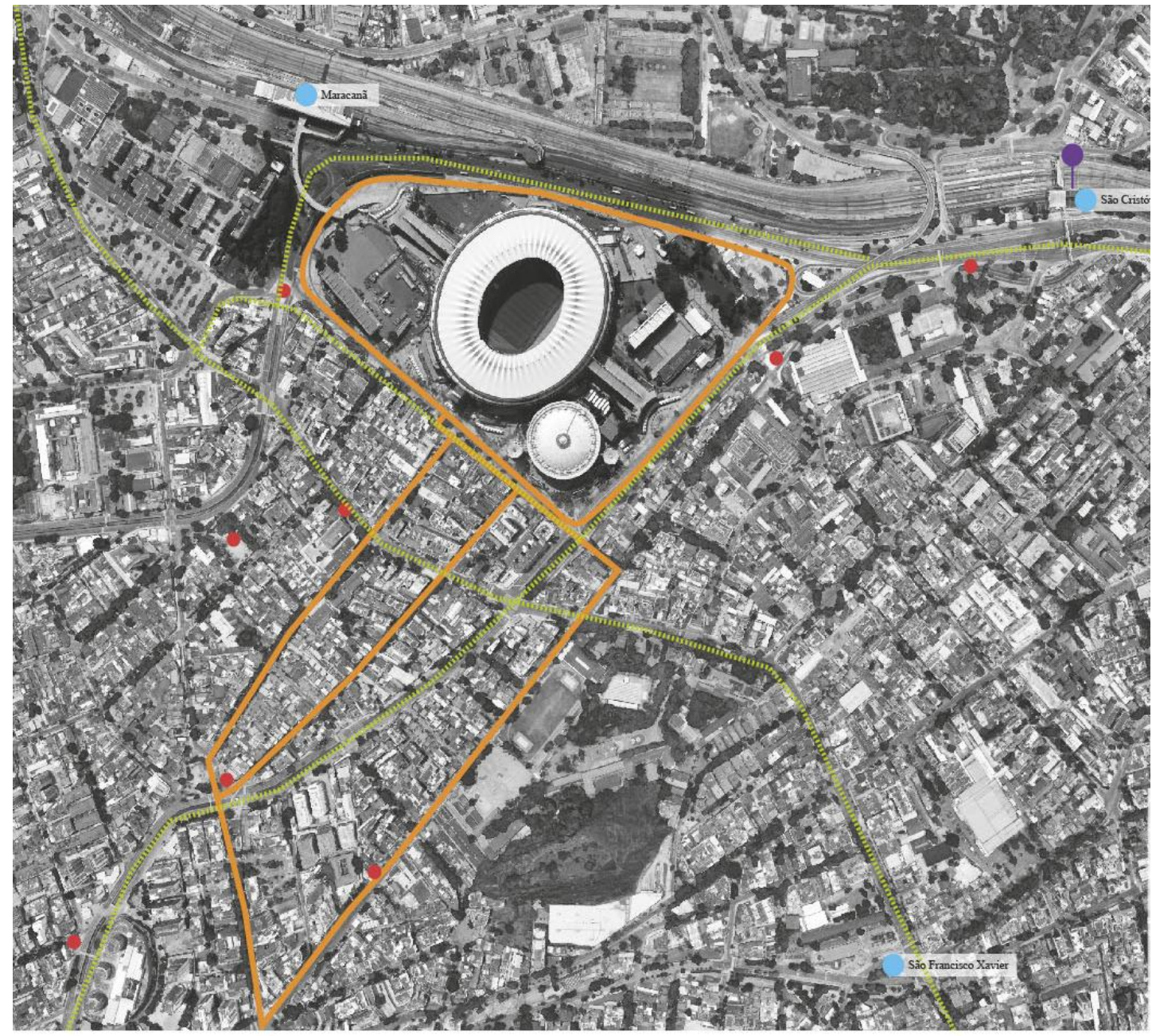

LEGENDA

- Sistema cicloviário

- Bicicletário

Estação de Metrô

Principais corredores de ônibus

- Estacionamento
Mapa 12 : Mobilidade Urbana

Escala gráfica

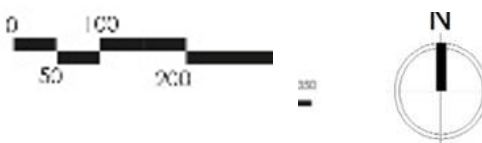

Fonte: Google Earth , trabalhado pelos autores, 2020. 


\subsection{O Clube de Regatas Flamengo e sua megatorcida}

Escolheu-se para exemplificar as condições colocadas acima, os jogos de um time de futebol com a maior torcida do Rio de Janeiro realizados no Estádio estudado, o Clube de Regatas do Flamengo que impactam de forma significativa a área (Tabela 2).

Tabela 2: Tabela com jogos do Flamengo de 2019 em que implementaram o protocolo de segurança no Maracanã.

\begin{tabular}{|c|c|c|c|c|c|c|c|}
\hline Data & jogo/ placar & fase & Tipo & $\begin{array}{c}\text { Dia da } \\
\text { semana }\end{array}$ & hora & $\begin{array}{l}\text { Protocolo } \\
\text { segurança }\end{array}$ & $\begin{array}{c}\text { Fechamento } \\
\text { das ruas }\end{array}$ \\
\hline $23 / 10 / 2019$ & Fla 5 X 0 Grêmio & Semi & Libertadores & $4^{a}$ feira & $21: 30$ & Vermelha & \\
\hline 27/10/2019 & Fla 1 X 0 CSA & $\begin{array}{l}\text { Pontos } \\
\text { corridos }\end{array}$ & Brasileiro & Domingo & 19:00 & Amarela & \\
\hline $10 / 11 / 2019$ & Fla $3 \times 1$ Bahia & $\begin{array}{l}\text { Pontos } \\
\text { corridos }\end{array}$ & Brasileiro & Domingo & 18:00 & Amarela & \\
\hline
\end{tabular}

Para se precaver dos transtornos, no dia $1^{\circ}$ de setembro de 2019 se instituiu um protocolo de segurança. O ministério Público do Estado do Rio de Janeiro - MPRJ, por meio do Grupo de Atuação Especializada do Desporto e Defesa do Torcedor - GAEDEST/MPRJ, a Federação de Futebol do Estado do Rio de Janeiro - FERJ, e os órgãos de planejamento do GT Maracanã criaram um programa de segurança e estabelecem três áreas: matriz de atribuição das medidas e ações; modelos de planos de ação; e critérios para auxiliar a classificação de risco. Foi gerado um software denominado Metodologia de Avaliação de Riscos em Estádios de Futebol - AREF - desenvolvido pela Agência Brasileira de Inteligência - ABIN, destinados aos jogos realizados no Maracanã.

Durante o ano de 2019, o Clube de Regatas Flamengo venceu todos os campeonatos nacionais, regionais e internacionais que aconteceram no Estádio do Maracanã, aumentando ainda mais a frequência dos espectadores (Fla sócio torcedor, 2019). O maior público deste ano no Estádio foi de 65.649 torcedores na ocasião do Campeonato Brasileiro quando jogavam Flamengo e Bahia. Foi o primeiro jogo do ano a instituir o protocolo de segurança implementado pelos órgãos públicos para proteger o espaço urbano dos torcedores e vice-versa, que se utilizavam de bandeiras coloridas (verde, amarela, laranja e vermelha) para especificar o nível de risco dos eventos e determinar efetivos de segurança e interdição de vias. Este jogo foi classificado como bandeira amarela, por considerar o jogo como de torcida.

Dentre todos os jogos que aconteceram no Maracanã verificamos que os mais importantes ocorreram às quartas e quintas feiras, à noite, às $21: 30 \mathrm{~h}$, em função da transmissão televisiva e pela menor circulação de pessoas nas ruas do entorno. A média elevada de público trouxe transtornos para a dimensão local e região metropolitana tais como congestionamento no trânsito, problemas de segurança no entorno e que se estenderam aos bairros vizinhos. 
No jogo Flamengo e Grêmio a bandeira vermelha exemplifica as medidas excepcionais que se fizeram necessárias. Vias foram interditadas ao redor do estádio, com o fechamento de um dos sentidos da Avenida Radial Oeste e o Batalhão de Polícia de Choque estava presente. Além da interdição para automóveis em vias de rolamento do entorno, houve também para o transeunte um impedimento para se locomover no calçadão do estádio, permitindo a passagem apenas de quem possuísse ingresso.

\section{Metodologia da Pesquisa}

Para entender como se dá a apropriação dos usuários com todos os procedimentos de segurança nos dias de evento, especificamente em dias de jogos do Flamengo, utilizou-se da metodologia de percurso comentado de Thibaud (2008) onde foi de vital importância a observação de "ver e viver" a região na pesquisa de campo, que ocorre através da relação do usuário com o espaço construído, na interação, percepção e representações.

Essa interação, segundo Thibaud (2008), na pesquisa de campo se dá por caminhadas, experiências vividas, Eu, Tu, Ele, caminhando com três pessoas expondo as relações de suas emoções. O "Eu" neste estudo representa os pesquisadores, que experimentam a caminhada livre anotando os registros de campo, as impressões e sensações sucessivas ao caminhar. Já o "Tu" refere-se à fala do outro e consiste em escutar os usuários, caminhando junto aos pedestres que se encontram no lugar, podendo ser habitantes locais, usuários ou torcedores. A aproximação etnográfica a partir do "Ele", diz respeito à verificação do ritmo dos transeuntes em diversas horas do dia, os quais foram observados à distância, em um ponto específico para que fosse possível identificar o tempo e fluxo da evacuação dos torcedores.

As escolhas do percurso dependeram de várias condições do evento no estádio, que consideraram tanto experiências pessoais como as manifestações e de captação das comunicações das representatividades das relações do lugar. A experiência urbana, mais o ver e o viver urbano do outro, pode ajudar a indicar a sociabilidade do lugar e está atrelada à direção do fluxo dos torcedores, uma vez que os corpos em movimento se inscrevem no contexto e são pontuados pelos trajetos topológicos e pelos momentos de interações sociais e trajetos cognitivos. Assim, gradualmente o lugar se qualifica pelas escolhas e formas individuais de se deslocar. Chamamos também, aqui na pesquisa, de "pesquisador sombra", quando se caminha junto à multidão de torcedores. Esse tipo de investigação revela que a caminhada não procede somente de uma experiência "na" cidade ou mesmo "da" cidade, mas também "com" ela (THIBAUD, 2008).

O caminhar é uma forma etnográfica de leitura das representações sociais, que analisa os gestos, posturas, olhares e falas enquanto etapas de um trabalho de campo. Permite captações por áudio e vídeo e, consequentemente, voltar várias vezes ao lugar através das imagens e palavras registradas. Através dos trajetos topológicos e cognitivos Thibaud (2000) chamou essa forma de avaliação de "método do percurso comentado", cujo objetivo central é captar a experiência sensível, a experiência emocional, mediante a percepção e representação em movimento, utilizando três atividades simultâneas: "caminhar, perceber e descrever" (THIBAUD, 2000).

Os percursos foram escolhidos pelas características diferenciadas da paisagem urbana, morfológica e de uso e apropriação. Kohlsdorf (1996) afirma que os lugares podem oferecer informações relativas a uma série de aspectos da sua arquitetura, como as expectativas funcionais, estéticas, de conforto térmico, acústico ou luminoso, de apropriação social, e de orientação, dentre outros. O autor ainda acrescenta que a orientabilidade é a capacidade dos lugares, em termos de possibilidades oferecidas aos indivíduos, de se moverem neles e para fora dos mesmos, com uma finalidade consciente (KOHLSDORF, 1996). Assim, foram definidos três locais de análise denominados de pontos de referência, marcações visuais no contexto urbano. 
Para este estudo a interpretação do lugar e a análise qualitativa foram feitas através dos sentidos (visão, audição, cheiro e sensação térmica) e pelas dimensões culturais, de identidade e representações. A identificação visual espacial foi ainda dividida em três aspectos de qualificação do espaço urbano: sonoridade, elementos espaciais e sensações e sentimentos, úteis no estudo presencial detalhado a seguir.

\section{Estudo de Campo}

Este estudo se baseou no jogo Flamengo e CSA, no dia 27 de outubro de 2019, $28^{\text {a }}$ rodada do campeonato Brasileiro de 2019 e alcançou o maior público de todo o ano com 65.649 torcedores, vencendo o Flamengo por 1 a zero. A temperatura no dia era de $24^{\circ} \mathrm{C}$, ensolarado, e o horário do jogo foi às 19 horas. Chegou-se para o levantamento de campo às 16 horas. Os fluxos identificados neste evento estão representados abaixo. Os torcedores foram acompanhados em todos os acessos e saídas. No momento da evacuação percebeu-se o direcionamento das pessoas que seguiam as rotas para o transporte público ou estacionamentos. Os pontos marcantes foram o Shopping Tijuca (estacionamentos individuais) e as estações de metrô Maracanã, São Cristóvão e Saens Pena, além de pontos irregulares de taxi e Uber. As ruas onde ocorreram fluxos foram mais intensos foram as que margeiam o Estádio e aquelas de maiores proporções que radialmente se espraiam, como a avenida Maracanã, avenida Radial Oeste, continuação da rua Mata Machado (Figura 7).

Figura 7: Fluxos mais intensos na evacuação dos eventos e identificação dos portões de acesso.

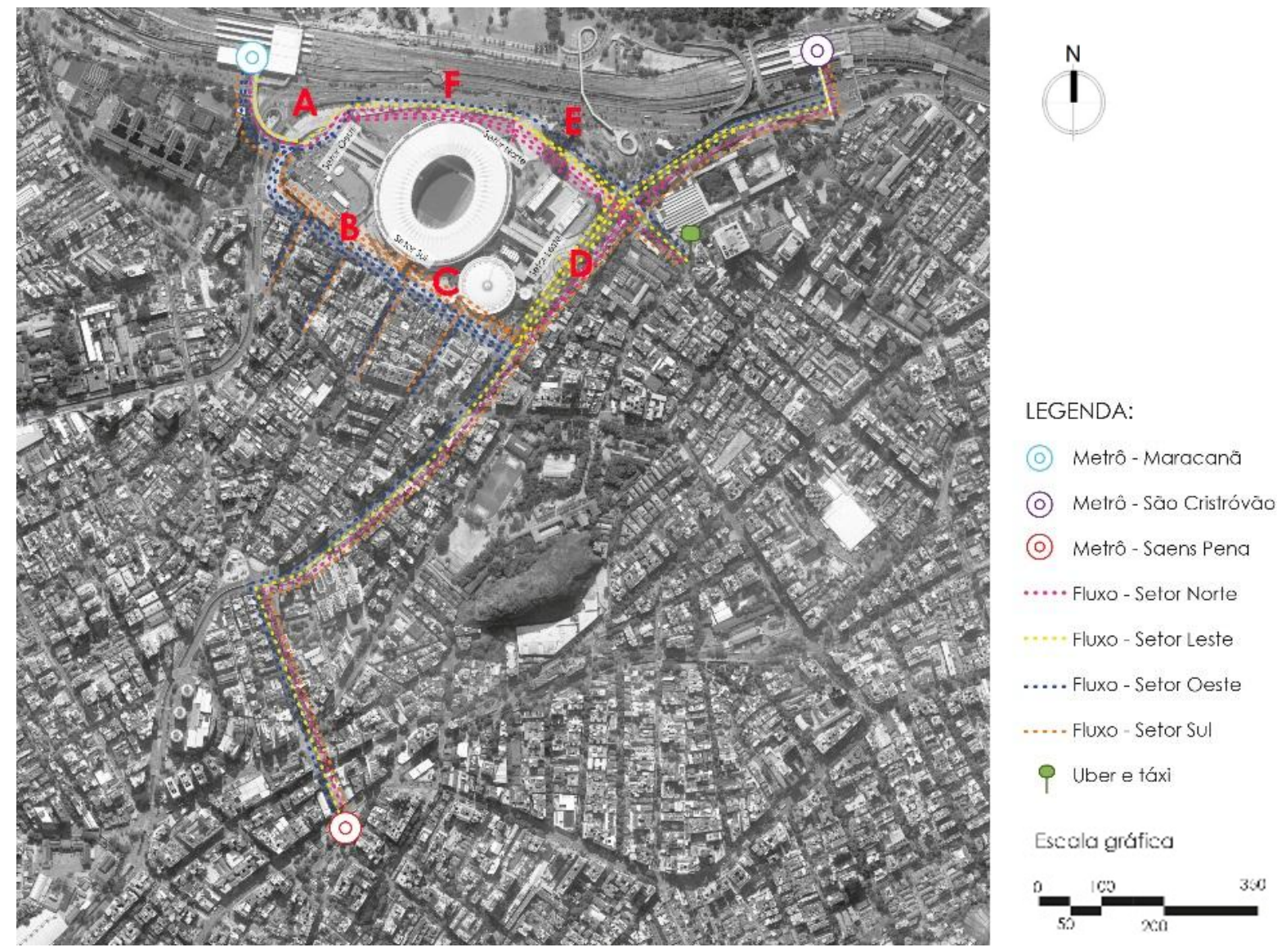

Fonte: Google Earth trabalhado pelos autores, 2020.

No Estádio os acessos do setor norte correspondem às letras "E" e "F", atendendo as arquibancadas dos níveis 2 e 5 e seu ingresso é mais barato; o setor sul recebe as letras " $B$ " e "C" referentes aos níveis 2 e 5, voltado para a avenida Radial Oeste; a área reservada aos visitantes é atingida pelo 
acesso "B", e o setor leste recebe a letra "D" sendo voltado para a estátua do "Bellini" marcado pela letra "A", na direção da UERJ e abriga os torcedores VIPs.

Para qualificar o espaço livre através percurso comentado foram analisados os seguintes atributos: sons, elementos espaciais, sensações, sentimentos, apropriações e barreiras físicas, naturais e móveis. Baseado na teoria de complexidade proposta por Morin (2002) entende-se que a importância tanto dos atributos qualificáveis (uso e função) como os cognitivos possuem pesos iguais.

No estudo da paisagem, a qualificação do espaço urbano se dá pela percepção do pedestre, mas é notório que as características da paisagem influenciam os fluxos, estando diretamente relacionadas aos seus atributos, tais como a presença de arborização, avenidas amplas, agradabilidade visual, bem como locais seguros para descanso.

O sombreamento da caminhada ao acompanhar os movimentos dos torcedores permitiu perceber onde e em que direção ocorrem as rotas e as atividades nelas desenvolvidas. A cartografia do percurso enquanto espaço-tempo dos sentidos (Tabela 3) apreende a sociabilidade e interações sociais (THIBAUD, 2000, 2018).

Tabela 3: Atributos de leitura do lugar.

\begin{tabular}{|c|c|c|c|c|c|c|}
\hline Sons & $\begin{array}{l}\text { Elementos } \\
\text { Espaciais }\end{array}$ & $\begin{array}{l}\text { Sensações e } \\
\text { Sentimentos }\end{array}$ & Apropriações & $\begin{array}{l}\text { Barreiras } \\
\text { Físicas }\end{array}$ & $\begin{array}{l}\text { Barreiras } \\
\text { Naturais }\end{array}$ & $\begin{array}{l}\text { Barreiras } \\
\text { Móveis }\end{array}$ \\
\hline $\begin{array}{l}\text { Apito de } \\
\text { trânsito }\end{array}$ & Maracanã & Segurança & $\begin{array}{l}\text { Grupo de } \\
\text { Conversa }\end{array}$ & $\begin{array}{l}\text { Carros de } \\
\text { polícia }\end{array}$ & Árvores & $\begin{array}{l}\text { Fluxo de } \\
\text { pessoas } \\
\text { contra }\end{array}$ \\
\hline Buzina & Maracanãzinho & Insegurança & $\begin{array}{l}\text { Grupo de } \\
\text { Policiais }\end{array}$ & $\begin{array}{l}\text { Ambulantes } \\
\text { Pessoas }\end{array}$ & Arbustos & $\begin{array}{l}\text { Automóveis } \\
\text { em vias } \\
\text { fechadas }\end{array}$ \\
\hline $\begin{array}{l}\text { Cantoria } \\
\text { dos } \\
\text { torcedores }\end{array}$ & Museu do índio & Cheiros & $\begin{array}{lr}\text { Sósias } & \text { dos } \\
\text { atletas } & \text { para } \\
\text { fotos } & \end{array}$ & $\begin{array}{l}\text { Ambulantes } \\
\text { Ciclísticos }\end{array}$ & & \\
\hline $\begin{array}{l}\text { Anúncio de } \\
\text { venda por } \\
\text { parte dos } \\
\text { ambulantes }\end{array}$ & $\begin{array}{l}\text { Rampa de } \\
\text { acesso ao metrô }\end{array}$ & Odores & & Lixo & & \\
\hline $\begin{array}{l}\text { Anúncio de } \\
\text { acesso ao } \\
\text { Estádio por } \\
\text { parte dos } \\
\text { ajudantes }\end{array}$ & Cartaz da Marta & Afetividade & & Grades & & \\
\hline $\begin{array}{l}\text { Grupo de } \\
\text { samba }\end{array}$ & $\begin{array}{l}\text { Estátua } \\
\text { Bellini }\end{array}$ & Agradável & & & & \\
\hline Falatório & Bares & Desagradável & & & & \\
\hline
\end{tabular}

Fonte: Autores, 2020

3 Vale lembrar que a estátua conhecida como sendo do Bellini é uma homenagem ao campeonato mundial de 1958 e não sua representatividade física. 


\subsection{Percursos Comentados}

Para esta avaliação executou-se um único Percurso Comentado analisado nas rotas 1 e 2. A rota 1 foi referente ao direcionamento de acesso ao jogo antes da partida, enquanto a 2 era relacionada à evacuação, após a partida. Assim, evidenciou-se que o mesmo percurso apresenta representações e legibilidades diferentes em situações e horários diversos. Foram ainda identificados os três pontos de referências de maior número de atributos percebidos, que no percurso 1 foram denominados de $A, B$ e C; no trajeto 2, foram chamados de C, B e A.

O percurso comentado 1 (rota de acesso) começou na rampa de acesso das estações ferroviária e metroviária e terminou na área mediana da avenida Eurico Rabelo, local correspondente à letra "C". A análise do ponto de referência " $\mathrm{A}$ " retratou um grande número de pessoas na descida da rampa por ter havido um desembarque na estação ferroviária. Deixou passar uma sensação de insegurança por haver moradores de rua e usuários de drogas sob a rampa, mas a caminhada ocorreu tranquila e fluida. Devido ao grande número de torcedores as análises foram percebidas sempre relacionadas às pessoas e não às estruturas físicas. Nas apropriações por parte dos usuários pôde-se notar a presença de muitos cambistas, polícias militares e municipais, ambulantes, falatório e cantoria dos torcedores denotando euforia.

O ponto "B" apresentou limitadores urbanos que são as grades de apoio aos jogos, o que não afetou o espaço livre e agradável. Havia muitos policiais sob a rampa e, pessoas apoiadas no guarda corpo do rio Joana, colaboravam com o movimento local.

O ponto de referência "C" exprimia uma área ampla e livre no sentido de ausência de mobiliário urbano, porém dotada de alto nível de ruído resultante do fluxo intenso de automóveis. Um agrupamento de pessoas conversava e bebia suas cervejas enlatadas. Agentes de segurança privados ajudavam guardar a segurança. $\mathrm{O}$ trânsito congestionado na avenida Eurico Rabelo causava conflito entre carros e pedestres antes do fechamento da via para os torcedores, estrangulando os passeios.

No Percurso Comentado 2, no horário e sentido de evacuação, os torcedores caminhavam cantando e pulando com a vitória do Flamengo. Extravasavam alegria sob o cheiro de cerveja, mas havia a sensação de segurança próximo aos policiais. Onde existia aglomeração, a sensação era contrária (Figura 8). 
Figura 8: Percurso comentado 1 e 2, rota de acesso e de evacuação.

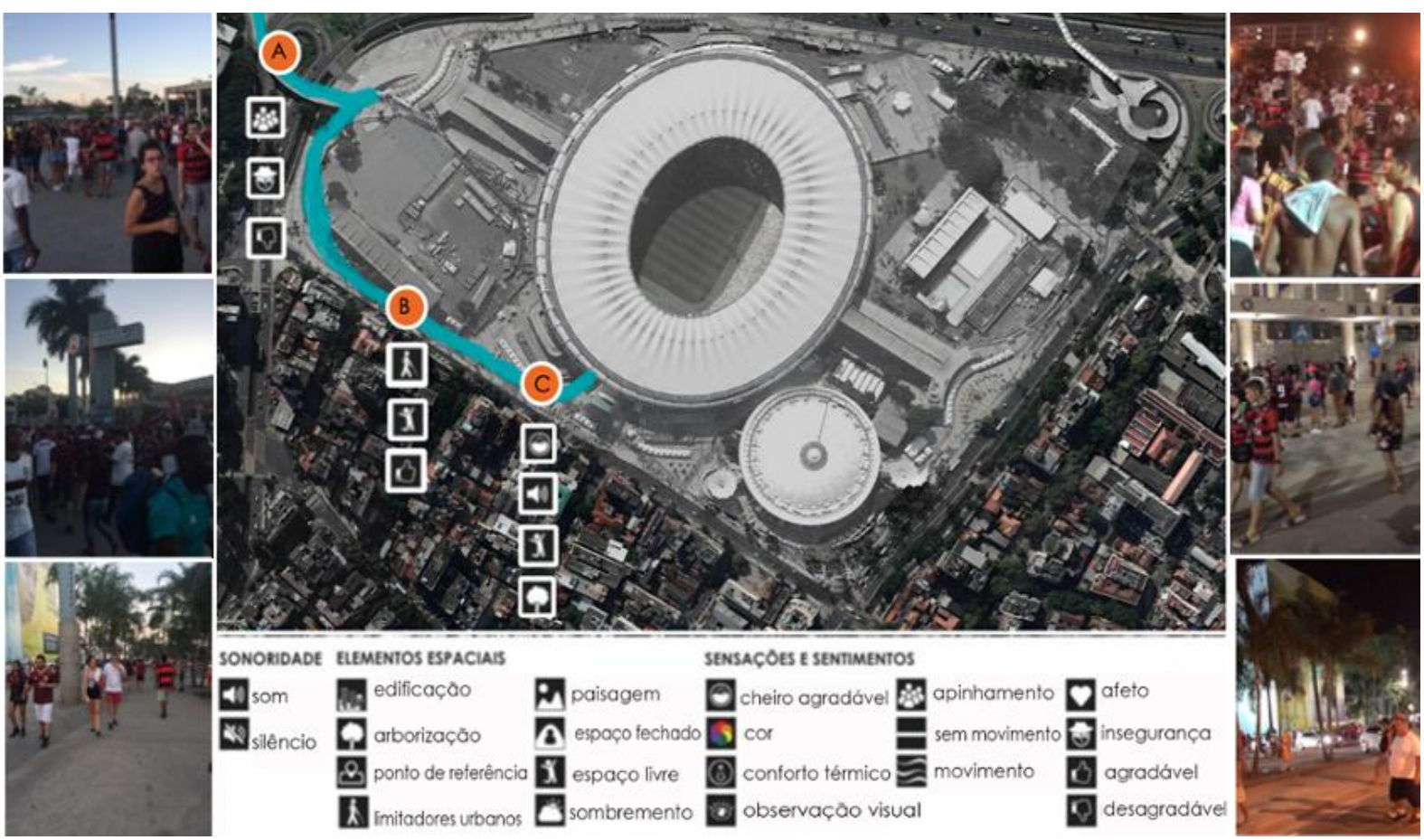

Fonte: Representação de Oliveira atualizada pelos autores, 2020

Os fluxos foram verificados na evacuação e a grande intensidade de torcedores na saída ocorre a partir dos 8 minutos de término de jogo, que vai se diluindo pelos próximos 16 e 24 minutos em menor escala, e começa efetivamente a diminuir após 40 minutos do término do jogo, e só cessa decorridos 48 minutos, mesmo que tenha sido projetado para que a evacuação fosse executada em 8 minutos, conforme padrão FIFA (Figura 9).

Figura 9: Estudo da evacuação - fluxo x intensidade

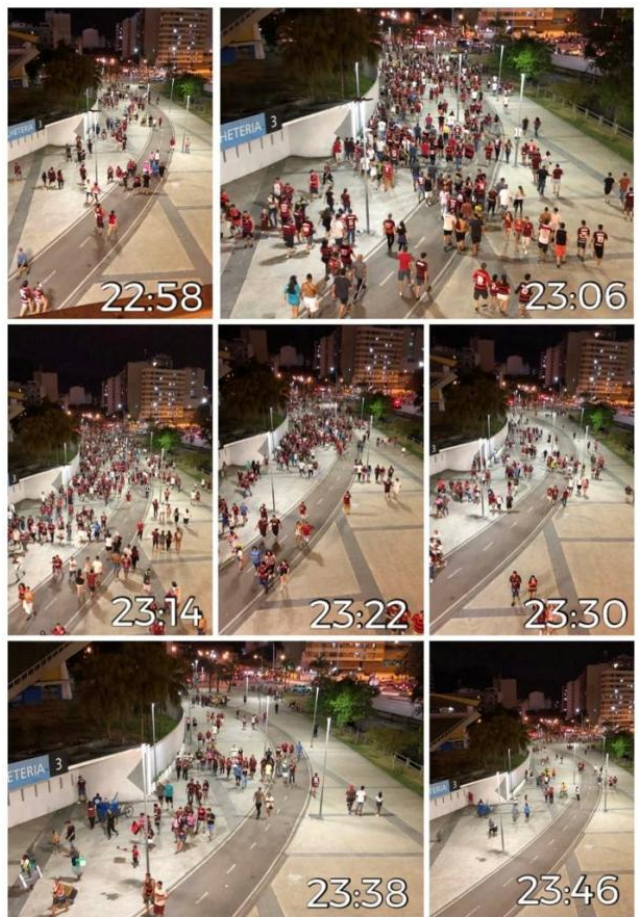

Fonte: Acervo autores, 2020. 
O Percurso Comentado foi aplicado com o pesquisador sombra caminhando junto ao torcedor e analisando a sua percepção. Foi registrado por vídeos e fotografias e representado cartograficamente, indicando as manchas de dispersão dos torcedores e os locais de concentração (THIBAUD, 2008).

Dessa maneira, também foi possível perceber as apropriações do local feitas por ambulantes vendedores de picolé em triciclo, único cadastrado e legalizado pela prefeitura, embora sejam encontrados ainda vendedores de algodão doce, de cachorro-quente, churros, pipoca, hambúrguer, churrasco, cervejas, refrigerantes, camisas, bonés e faixas de campeão. Para o evento estudado, situavam-se em todo o calçadão 69 ambulantes após o jogo na esquina da avenida Maracanã com Mata Machado. Antes do jogo, foram contabilizados 16 ambulantes na calçada em frente aos edifícios na avenida Maracanã e cerca de 20 na esquina da Mata Machado com Av. Maracanã.

\section{Atributos da Paisagem: Análise Qualitativa das Bordas}

A relação entre os espaços livres e construídos com a valorização das dinâmicas biofísicas e socioculturais aborda os princípios da paisagem introduzindo o conceito de sustentabilidade e da reflexão contemporânea. Os atributos socioculturais se apoiam em conteúdos sociais, percepções, expressões e representações da cultura (TARDIN, 2017). Os biofísicos se relacionam com a água, vegetação, topografia e solos, existente em escalas, permitindo que o contexto urbano se desenvolva através dos elementos estruturantes do espaço.

Considerados como atributos biofísicos, os rios Joana e Maracanã caracterizam a área e limitam os atributos hidrológicos da borda que permitiram compreender a percepção da paisagem "cotidiana" delimitada pelo contexto espacial. Já a linha férrea rompe com o tecido urbano e desconecta bairros vizinhos; seus muros restringem o espaço livre da borda ao norte e configuram barreiras física, funcional e visual. Este fluxo gerou um mapa com localização da ocupação das manchas sem especificar as intensidades de fluxos (Figura 10).

Figura 10: Borda Cotidiana (1), Borda Acessível (2) e Borda Global (3).
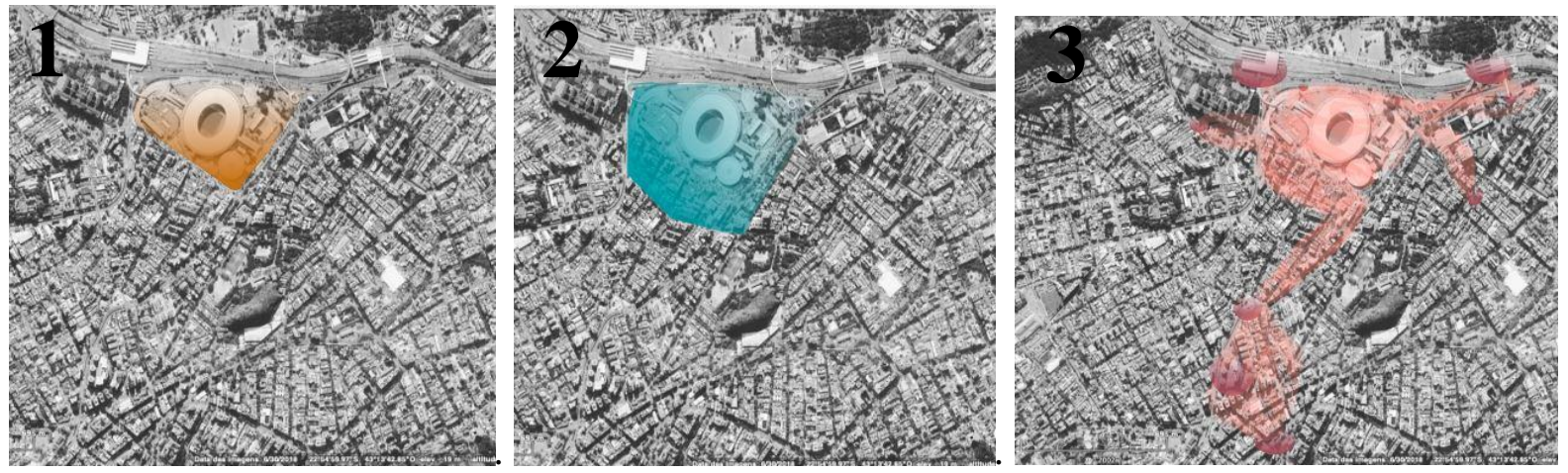

Fonte: Google Earth trabalhado pelos autores, 2020.

A "Borda Acessível" foi delimitada pelos planos de fechamentos de ruas que acontece em todos os eventos no estádio do Maracanã. A cada jogo que ocorre, de acordo com seu plano de segurança, altera a mobilidade cotidiana da área, dos bairros vizinhos e até da cidade como um todo. $\mathrm{A}$ acessibilidade do cotidiano da urbe se modifica em função espetáculo local caracterizando a "Borda Acessível" que durante o evento passa a atender ao "cidadão do espetáculo" e não mais a cidade. A "Borda Global" foi caracterizada pelo direcionamento dos fluxos de evacuação dos eventos em direção aos modais de transportes públicos como metrô e trem, estacionamentos oficiais e não oficiais, pontos de ônibus, pontos de taxis e transportes de aplicativos irregulares nos arredores. A acessibilidade ao local por transporte público é muito bem servida. As rotas são contínuas, sem barreiras físicas, 
conforme a NBR 9050, norma brasileira de acessibilidade.

A borda não está provida de cobertura vegetal; a vegetação arbórea existente não chega a 10\% da área e mesmo assim o plantio é pontual e heterogêneo, com densidade de sombra rala. O solo é quase $100 \%$ impermeabilizado aumentando a sensação de calor no local. O terreno encontra-se em área adensada e margeado por vias arteriais e coletoras, pelas avenidas Radial Oeste, Av. professor Manoel de Abreu, Av. Maracanã e Eurico Rabelo ocasionando tráfego intenso. O local não é detentor de fachadas ativas e a passagem das pessoas se deve ao transporte público, edifícios educacionais e de saúde ao redor. A iluminação se adequa à borda com posteamentos com luminárias em led e de várias alturas alcançando a área como um todo.

Apresenta desequilíbrio entre lazer ativo e passivo, onde o passivo é inexistente. As atividades exercidas na borda despertam o interesse de poucos usuários, apenas para o lazer ativo. Durante os dias de semana há frequentes caminhadas, corridas tipo cooper, ginásticas funcionais; nos finais de semana existem também outras atividades além das mencionadas, como ainda crianças andando de bicicleta, de patins, skate, e jogos de futebol de crianças com os pais em áreas livres amplas, mas sem especificação física. Todas essas análises evidenciam o quanto a qualidade do espaço deixa a desejar.

\section{Considerações finais}

A evolução urbana da área sempre esteve vinculada aos propósitos políticos da primeira capital do país. A biografia do Estádio do Maracanã, em uma primeira fase, vivencia o nacionalismo com a sua própria construção. Posteriormente, se pode observar a monumentalidade da edificação e de seu espaço livre derivado da sua borda física, vivida e percebida pela sua "borda cotidiana" que está incorporada na memória afetiva da população. Em um terceiro momento, se valendo da "paixão nacional pelo futebol", o Estádio e sua borda se apresentam como referência brasileira e internacional onde os fenômenos globais interferem nas culturas locais, causando desintegração sócio espacial.

Os parâmetros FIFA para a reforma do Estádio do Maracanã além de não atenderem aos usuários do cotidiano e da população local, também não atendem aos parâmetros de uma maneira geral e, especificamente, ao que tange à evacuação dos usuários do Estádio. O limite oficial e vivido da "borda global" embasada nos atributos socioculturais em dias de eventos margeia as ruas no entorno do estádio e se expande até à praça Seans Pena, impactando toda a vizinhança.

Os edifícios-estádios são projetados para uma imensidão de torcedores gerando um grande fluxo em dias de evento. Assim, há uma existência de conflito; ao mesmo tempo em que é uma celebração, é também um transtorno com as interdições do tráfego atraindo para a vizinhança multidões provocando os sentimentos topofilia (elo afetivo entre pessoas e ambientes físicos) e topofobia (medo de um lugar ou região). A "borda acessível" passa a atender ao "cidadão do espetáculo" e não mais a cidade democrática, fato correlacionado ao fenômeno de "não lugar".

As análises deste estudo permitiram concluir que a falta de vegetação, impermeabilização de toda a área, a falta de mobiliário urbano e equipamentos de lazer passivo são alguns elementos que determinam a subutilização da borda cotidiana. Para minimizar os impactos negativos e maximizar os positivos para fora dos limites de seus muros pressupõe-se um espaço de entretenimento e lazer para os indivíduos com todos os atributos paisagísticos necessários para a qualificação espacial urbana do espaço livre.

Dessa forma, o artigo induz a uma reflexão sobre os prós e contras dos protocolos da FIFA para uma área de acontecimentos esportivos, aqui no caso, o Estádio do Maracanã, visando a segurança em relação aos seus moradores e aos torcedores dos times de futebol que frequentam a referida arena. 
Verificou-se, ainda, que certas áreas da borda que circunda o Maracanã ficam fora das rotas de evacuação em dias de jogos e assim, poderiam ser locais mais bem servidos de mobiliário urbano e arborização, possibilitando uma maior utilização cotidiana, principalmente pelos moradores do lugar.

O protocolo de segurança da FIFA oferece a sensação de um ambiente seguro para os torcedores, mas esse efeito se restringe às áreas interditadas uma vez que, em seus limites, a presença de cambistas e traficantes leva à sensação contrária, causando aos moradores um problema em dias de jogos. Finalmente, acredita-se que este trabalho, ao observar os diferentes modos de experimentação da borda do Maracanã, serve como um novo caminho para repensar o papel do Edifício-Estádio além de suas fronteiras, instigando pesquisas e práticas futuras.

\section{Referências}

AUGÉ, Marc. Não-lugares: introdução a uma antropologia da supermodernidade. São Paulo: Papirus, 1994.

ARROYO, Julio. Espacio público. Fenomenologías complejas y dificultades epistemológicas. Apresentação aceita no VII Seminário de História da Cidade e do Urbanismo, Universidade Federal de Bahia, 2002.

CULLEN, G. Paisagem urbana. São Paulo: Martins Fontes, 1983.

Flamengo sócio torcedor, 2019. https://www.nrnoficial.com.br. Acesso em dezembro 2019.

Guia de Recomendações de Parâmetros e Dimensionamentos para Segurança e Conforto em Estádios de Futebol, Fundação Getúlio Vargas, Rio de Janeiro, 2010.

FIFA - FEDERAÇÃO INTERNACIONAL DE FUTEBOL. Estádios de Futebol - Recomendações e Requisitos Técnicos. 5a Edição. Suíça: FIFA, 2011.

FIFA. Football Stadiums: Technical recommendations and requirements. 4a edição. Suíça: FIFA, 2007.

Jornal O Globo,1992. Acesso em acervo histórico em janeiro 2020.

KOHLSDORF, M. E. A apreensão da forma da cidade. Brasília: Ed. UnB, 1996.

LYNCH, Kevin. A imagem da cidade. (Trad. M. C. T. Afonso) Lisboa: Edições 70, 1982 [1960].

MACEDO, Sílvio Soares. Os sistemas de espaços livres e a constituição da esfera pública contemporânea no Brasil: uma rede de pesquisas em âmbito nacional. Coleção paisagens culturais. Rio de janeiro, v. 3, p. 286-297, 2008.

Os sistemas de espaços livres na constituição da forma urbana contemporânea no Brasil: produção e apropriação (QUAPA-SEL II). Paisagem e Ambiente. São Paulo, n.30, p.137-172, 2012.

MORIN, Edgard. O Método 2: A vida da vida. Tradução Marina Lobo. Porto Alegre: Sulinas, $2^{\underline{a}}$ ed, 2002.

OLIVEIRA, Juliana Simili de. Rio de Janeiro, 2017. PAISAGEM SONORA ALÉM DA AUDIÇÃO: representações sonoras urbanas das pessoas surdas. Tese (Doutorado em Arquitetura) - Programa de Pós-graduação em Arquitetura - PROARQ, Faculdade de Arquitetura e Urbanismo, Universidade 
Federal do Rio de Janeiro, Rio de Janeiro, 2017.

TARDIN. R. Arquitetura Paisagística: Arte, Natureza e Cidade. Rio Books. PROURB. 2017.

TUAN, Yi-Fu. Espaço e Lugar: a perspectiva da experiência. Trad. Lívia de Oliveira. São Paulo: Difel, 1983.

Topofilia: um estudo da percepção, atitudes e valores do meio ambiente. Trad. Lívia de Oliveira. São Paulo: Difel, 2012.

THIBAUD, JP. Je, Tu, II. La marche auxtrois personnes. Urbanisme. n.359, Mars-Avril, pp. 63-65, 2008. Disponível em: <http://doc.cresson.grenoble.archi.fr/opac/doc_num.php?explnum_id=331 >. Acesso: Abril 2017.

La méthode des parcours commentés. In: GROSJEAN, M.; THIBAUD, J.P. L'espace urbain en méthodes. Marseille: Parenthèses, 2000.

A cidade através dos sentidos. CADERNO PROARQ, 2018.

\section{Adriane Pacheco Chaves}

Doutora em Arquitetura - PROARQ - FAU - UFRJ. (Tese: As Dinâmicas do Maracanã e sua influência na Construção da Paisagem Urbana. Orientadoras: Andréa Rêgo e Sylvia Rola). Mestre em Arquitetura - PROARQ - FAU - UFRJ/2001. (Dissertação - Espaço e Qualidade: Habitação de Interesse Social 1990-1999. Orientador Mauro Santos). Graduação em Arquitetura e Urbanismo pela Universidade Santa Úrsula (1992). Minha experiência profissional acadêmica como docente na área de Arquitetura e Urbanismo ocorre desde 2001. Universidades que atuei como professora substituta UFRJ e UFRRJ e como professora assistente por 13 anos na UNIPLI. Disciplinas Ministradas: projeto de arquitetura, urbanismo e paisagismo, desenhos técnicos, representação gráfica, instalações de saneamento ambiental e predial. Pesquisas Relevantes: 2012: Estudo para Elaboração de novos procedimentos para Aprimoramento dos Laudos Técnico em Estádios de Futebol. (IVIG-FAU-UFRJ) 2014: Sustentabilidade Ambiental em Estádios de Futebol: Estudo de Adequação das 12 Arenas da COPA DO MUNDO DE 2014 ã realidade Legal Brasileira.(IVIG-FAU-UFRJ) Experiência com atividades técincas: Projeto arquitetônico, complementares e gerenciamento de execução de 6.500 unidades habitacionais de interesse social pelo sudeste do país, Projetista no projeto Favela Bairro Pereirão e Urubu, responsável técnica pelo projeto do Minha Casa Minha Vida- PAC-MCMV- Itambi-Itaboraí- RJ, elaboração e execução de vários projetos de residências unifamiliares e reformas em geral.

Contribuição de coautoria: fundamentação teórico-conceitual e problematização; pesquisa de dados e análise estatística; elaboração de figuras e tabelas; Fotos; elaboração e redação do texto; seleção das referências bibliográficas; revisão do texto.

\section{Andrea Queiroz Rego}

Diretora da Faculdade de Arquitetura e Urbanismo da Universidade Federal do Rio de Janeiro, FAUUFRJ (2018-2022). Professora Associada do Departamento de Urbanismo e Meio Ambiente (DPURFAU-UFRJ). Docente permanente do Programa de Pós-graduação em Arquitetura, PROARQ-UFRJ, onde atuou como Coordenadora Adjunta de Pesquisa (2015-2017) e Vice-Coordenadora (2014-2015). Conselheira Titular do Conselho de Ensino de Graduação, CEG-UFRJ (2016-2019). Diretora Adjunta de Graduação, FAU-UFRJ (2014-2018) e membro do Núcleo Docente Estruturante (2012-2018).

Contribuição de coautoria: fundamentação teórico-conceitual e problematização. 


\section{Sylvia Meimaridou Rola}

Graduada em Arquitetura e Urbanismo pela Universidade Federal do Ceará (1994). Especialista em Design de Estruturas pela Universidade Pontifícia Católica do Rio de Janeiro (PUC, 1997). Mestre em Arquitetura pelo PROARQ/FAU/UFRJ (2000), com ênfase em Racionalização da Construção. Especialista e em Sustentabilidade das Cidades pela Universidad Atónoma Chapingo, no México (2001). Doutora em Planejamento Energético pelo PPE/COPPE/UFRJ (2008). Pesquisadora do Instituto Virtual Internacional de Mudanças Globais -IVIG/COPPE/UFRJ - desde 2001. Professora Adjunto do curso de Arquitetura e Urbanismo da Universidade Federal Rural do Rio de Janeiro, de 2009 até 02/2012. Professora Adjunto, desde 02/2012. Diretora Adjunto de Extensão de 2014/01 a 2018/01, da Faculdade de Arquitetura e Urbanismo da Universidade Federal do Rio de Janeiro. Diretora Adjunto de Graduação de 2020/01 a 2022/01. Atua principalmente nos seguintes temas: tecnologia, eco-construções, materiais não energo-intensivos, naturação (telhados verdes), meio ambiente, eficiência energética, Conforto Ambiental, sustentabilidade das cidades e das construções, avaliação de estádios de futebol, emissões de gases de efeito estufa (GEE) e mudanças climáticas.

Contribuição de coautoria: fundamentação teórico-conceitual e problematização.

Como citar: CHAVES, Adriane. REGO, Andrea Q. ROLA, Sylvia M. As percepções da paisagem e as diferentes dinâmicas da borda do Maracanã. Revista Paranoá. n.31. Jul/dez de 2021. DOI:

http://doi.org/10.18830/issn.1679-0944.n31.2021.01

Editores: Carolina Pescatori e Gabriela Tenório 